\title{
Fragile X: Leading the Way for Targeted Treatments in Autism
}

\author{
Lulu W. Wang, ${ }^{* \dagger}$ Elizabeth Berry-Kravis, ${ }^{*}$ and Randi J. Hagerman*广 \\ *Department of Pediatrics and the ${ }^{\dagger}$ M.I.N.D. Institute, University of California, Davis, School of Medicine, Sacramento, \\ California 95817; ${ }^{\ddagger}$ Departments of Pediatrics, Neurological Sciences, and Biochemistry, Rush University Medical Center,
} Chicago, Illinois 60612

\begin{abstract}
Summary: Two different mutations in the FMRl gene may lead to autism. The full mutation, with $>200$ CGG repeats in the $5^{\prime}$ end of $F M R 1$, leads to hypermethylation and transcriptional silencing of FMRI, resulting in absence or deficiency of the protein product, FMRP. Deficiency of FMRP in the brain causes fragile $\mathrm{X}$ syndrome (FXS). Autism occurs in approximately $30 \%$ of those with FXS, and pervasive developmental disorders-not otherwise specified occur in an additional $30 \%$. FMRP is an RNA binding protein that modulates receptormediated dendritic translation; deficiency leads to dysregulation of many proteins important for synaptic plasticity. Group I metabotropic glutamate receptor (mGluR1/5) activated translation is upregulated in FXS, and new targeted treatments that act on this system include mGluR5 antagonists and GABA agonists, which may reverse the cognitive and behavioral def-
\end{abstract}

icits in FXS. Matrix metalloproteinase 9 (MMP-9) is one of the proteins elevated in FXS, and minocycline reduces excess MMP-9 activity in the Fmrl knockout mouse model of FXS. Both minocycline and mGluR5 antagonists are currently being evaluated in patients with FXS through controlled treatment trials. The premutation (55-200 CGG repeats) may also contribute to the mechanism of autism in approximately $10 \%$ of males and $2-3 \%$ of females. Premutations with $<150$ repeats exert cellular effects through a different molecular mechanism, one that involves elevated levels of FMR1 mRNA, CGG-mediated toxicity to neurons, early cell death, and fragile $\mathrm{X}$-associated tremor/ataxia syndrome. In those with large premutations (150-200), lowered levels of FMRP also occur. Key Words: Fragile X syndrome, autism, ASD, mGluR, GABA, treatment, animal model.

\section{INTRODUCTION}

Fragile $\mathrm{X}$ mutations cause a family of fragile $\mathrm{X}$-associated disorders, including primary ovarian insufficiency (FXPOI), the fragile X-associated tremor/ataxia syndrome (FXTAS), and fragile X syndrome (FXS). Fragile X syndrome is caused by a CGG repeat expansion mutation ( $>200$ repeats, full mutation) in the promoter of the fragile $\mathrm{X}$ mental retardation 1 gene $(F M R l)$, and is the leading inherited cause of intellectual disabilities and the most common single-gene disorder associated with autism. ${ }^{1-3}$ Fragile $\mathrm{X}$ syndrome can be found in 1 in 2500-4000 individuals in the general population. ${ }^{4,5}$ The FMRI premutation (55-200 CGG repeats) is more common than the full mutation; it occurs in 1 in 130-250 females and 1 in 250-810 males in the general population. ${ }^{4-6}$

The FMRI gene was identified in $1991 .^{7}$ Subsequent molecular advances have shown that FMRP is an RNA

Address correspondence and reprint requests to: Lulu W. Wang, M.D., M.I.N.D. Institute, University of California, Davis Health System, 2825 50th Street, Sacramento, CA 95817. E-mail: lulu.wang@ ucdmc.ucdavis.edu. binding and transport protein that regulates the translation of many other genes at the synapse. FMRP usually acts in concert with multiple other signaling proteins to inhibit the translation of numerous genes involved in synaptic plasticity. Thus, the absence of FMRP, which leads to FXS, is associated with upregulation of many proteins. ${ }^{89}$ Some of the proteins that are regulated directly by FMRP or that interact with signaling cascades through which FMRP modulates translation are also associated with autism when their genes are mutated, including neuroligins, neurorexin 1, PTEN, PSD95, MAPK1, and SHANK3. The molecular overlap between FXS and autism is thus based on the dysregulation of genes related to autism in the absence of FMRP (FIG. 1).

Males with the full mutation in FMRI have $>200$ CGG repeats in the $5^{\prime}$ untranslated region of the gene, resulting in methylation and transcriptional silencing of the gene and therefore significant deficiency or absence of FMRP. This is the cause of FXS. The level of intellectual ability in FXS correlates positively with the level of FMRP. ${ }^{10,11}$ Those with both autism and FXS typically have a lower IQ than do those with FXS but not au- 


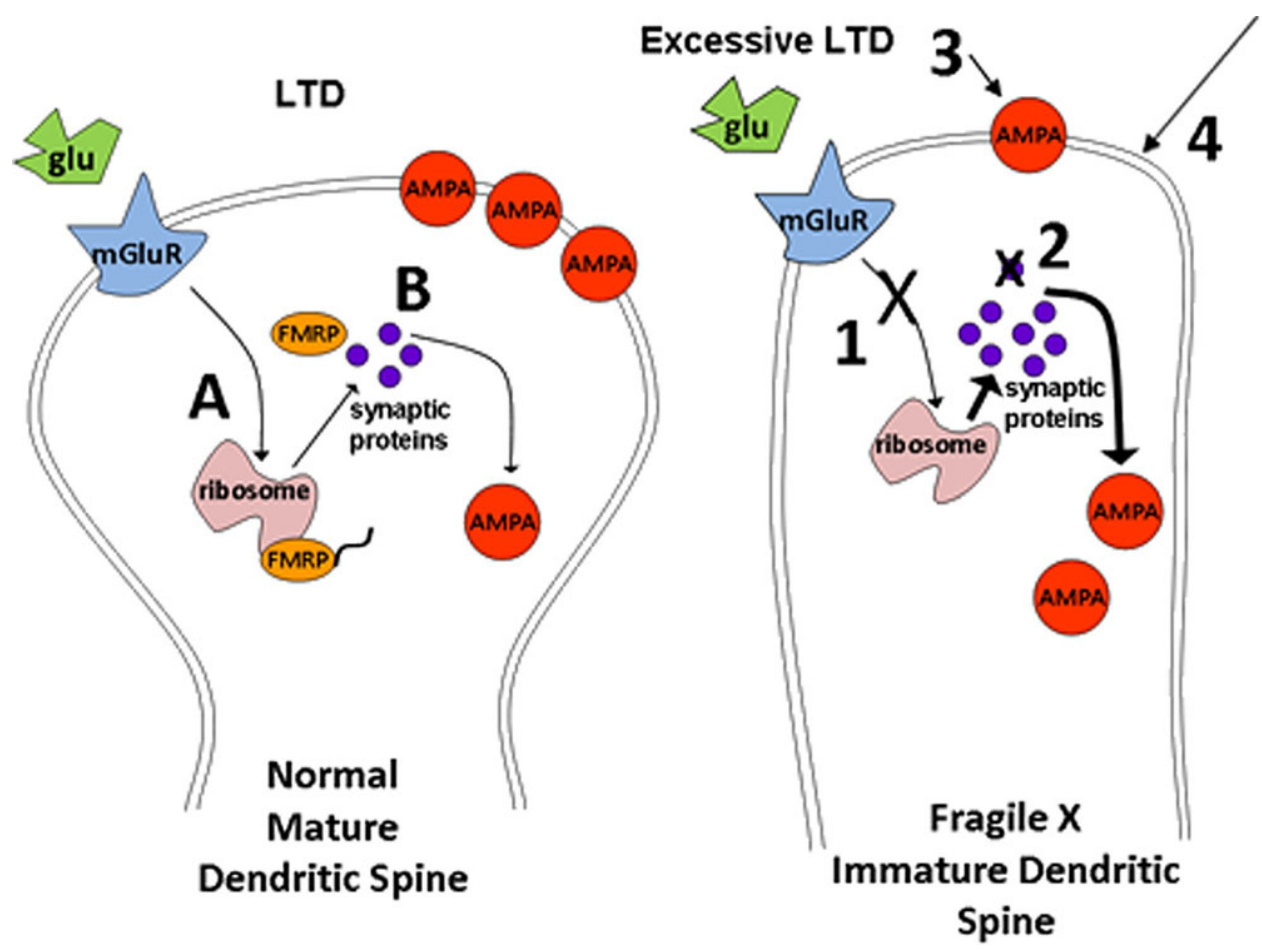

FIG. 1. Pathway thought to be involved under the mGluR theory of mental retardation in cortex and hippocampus in fragile $X$ syndrome (FXS), indicating levels of interaction of proteins mutated in autism with this pathway, and potential strategies for targeted treatment in the pathway. Left: In the normal dendritic spine, mGluR receptor activation by glutamate (glu) results in activation of dendritic translation via a signaling cascade including but not limited to phospholipase C (PLC), PI3K, PDK 1/2, Akt, ERK 1/2, mTOR, S6K, and PP2A. This cascade is modulated by numerous other synaptic signaling proteins. The main cascade proteins and modulators are represented as "A" in the model, and many proteins that would fall in the "A" category have been implicated in the autism phenotype, including mTOR and PTEN. Activation of the mGluR pathway results in mRNA release from FMRP and loss of inhibition of mRNA translation, giving an increased level of FMRP-regulated proteins at the synapse, and AMPA receptor internalization. FMRP is generated during this process as well, resulting in inhibitory feedback on translation, stabilization of synaptic protein levels at the needed levels based on neuronal activity, and maintenance of correct levels of surface AMPA receptors and LTD. Proteins derived from RNA cargos of FMRP, whose synaptic levels are regulated by FMRP represent category "B" of potential molecular overlap with autism-implicated proteins, including proteins such as PSD95. Right: In the FXS dendritic spine, which is immature, when FMRP is missing, mGluR-mediated translation lacks the inhibitory feedback balance normally provided by FMRP and is excessively and constitutively activated, leading to excessive synthesis of specific synaptic proteins that are derived from FMRP RNA cargos. This results in excessive internalization of AMPA receptors and other synaptic changes that result in excessive LTD and persistently weak and immature synapses. Potential strategies for treatment are indicated on the model and include 1) reduction of mGluR signaling either through extracellular receptor blockers or intracellular reduction of signaling pathway activity (MPEP and other mGluR5 blockers, lithium); 2) reduction of excessive activity of one or more key proteins normally regulated by FMRP (minocycline); 3) direct activation or restoration of surface AMPA receptors (ampakines/CX516); and 4) modulation of mGluR activity through other neurotransmitter receptors and systems (arbaclofen).

tism. ${ }^{12,13}$ If the IQ level is controlled for, however, the level of FMRP does not determine the presence or absence of autism. ${ }^{14}$ Seizures tend to co-occur with autism in FXS, and additional genetic mutations can also predispose an individual with FXS to have autism. ${ }^{15}$

Females with FXS have a full mutation on one of the X chromosomes but the other $\mathrm{X}$ has a normal allele. The $\mathrm{X}$-activation ratio, or the percentage of cells with the normal $\mathrm{X}$ as the active $\mathrm{X}$, determines how much FMRP is produced and therefore determines the intellectual level and physical involvement caused by the fragile $\mathrm{X}$ mutation. Approximately $25 \%$ of females with a full mutation have an IQ of $<70$, another $40 \%$ have an IQ in the borderline range (70-85), and $35 \%$ have an IQ in the normal range. Even with a normal IQ, however, learning disabilities, executive function deficits, and emotional problems are common in females with the full mutation. ${ }^{16-18}$

\section{PREMUTATION INVOLVEMENT}

For many years, carriers with the premutation (55-200 CGG repeats) were thought to be clinically unaffected. In 1991, however, Cronister et al. ${ }^{19}$ reported a high prevalence of early ovarian failure, relative to noncarriers or to those with the full mutation. This condition was confirmed at other centers and was renamed as primary ovarian insufficiency (POI) or, more specifically, as fragile X-associated POI (FXPOI). Ovarian failure before age 40 (early menopause) occurs in approximately $20 \%$ of premutation carriers, although an additional $20 \%$ experience hormonal dysregulation and menopause within the very early end of the normal range, before age $45^{20,21}$

In 2000, Tassone et al. ${ }^{22}$ reported elevated FMRI mRNA in premutation carriers: the higher the CGG re- 
peat, the greater the mRNA levels. Soon thereafter, tremor and ataxia were reported in some males over 50 years of age with the premutation. ${ }^{23}$ FXTAS was later reported in approximately $40 \%$ of older male carriers ${ }^{24}$ and in $8-16 \%$ of older female carriers. ${ }^{25-27}$

Elevated mRNA leads to a gain-of-function RNA toxicity that causes stress in the cells, with upregulation of heat shock proteins and alpha-B crystallin. ${ }^{25,28,29}$ In cells with the premutation, the lamin $\mathrm{A} / \mathrm{C}$ ring on the inside of the nucleus becomes disrupted and the cell may die more easily. ${ }^{29}$ Clinical features of FXTAS include an intention tremor, ataxia, neuropathy (which often includes pain in the lower extremities), cognitive decline, and autonomic dysfunction. Patients with FXTAS also have global brain atrophy and white matter disease in periventricular and subcortical regions, in addition to prominent involvement of the middle cerebellar peduncles (MCP sign). ${ }^{30}$ Neuropathological changes include eosinophilic inclusions in neurons and astrocytes throughout the brain, with the greatest density of inclusions in the hippocampus and limbic system. ${ }^{31}$ Inclusions can also occur outside of the CNS, including Leydig cells of the testicles ${ }^{32}$ and peripheral ganglia of the heart, GI system, and perivertebral ganglia. ${ }^{33}$

Additional medical problems can be seen in female carriers before the onset of FXTAS. Hypertension and neuropathy symptoms (including numbness, tingling, and pain in the lower extremities) are more common in female carriers than in control subjects. ${ }^{26}$ In addition, fibromyalgia (43\%) and hypothyroidism (50\%) are common diagnoses in female carriers with neurological problems, and these symptoms are more common in carriers than in control subjects. ${ }^{26}$

Cell cultures of neurons with the premutation demonstrate deficits in dendritic branching and early cell death. ${ }^{34}$ These findings are consistent with the developmental problems seen in some boys with the premutation. Farzin et al. ${ }^{35}$ compared boys with the premutation who presented clinically (probands), their premutation brothers identified by cascade testing (nonprobands), and brothers who did not have the premutation (control subjects). The rates of attention deficit hyperactivity disorder (ADHD) and autism spectrum disorder (ASD) were $90 \%$ and $73 \%$, respectively, in the probands, which was significantly higher than in the control subjects. The elements of ASD are autism, Asperger's disorder, and pervasive developmental disorders-not otherwise specified (PDD-NOS). The nonproband boys had rates of shyness and social deficits that were higher than for the control subjects, but the rate of ASD was only $8 \%$.

Similar rates of ASD and ADHD problems were seen in a study by Aziz et al. ${ }^{36}$ of boys with the premutation or a gray zone allele, and also in a survey of $>1200$ families, some of whom had a son with the premutation. ${ }^{37}$ In 30 adult men with the premutation, however,
Hunter et al. $^{38}$ did not find neuropsychological deficits compared with control subjects. In a similar study by Grigsby et al., ${ }^{39}$ who conducted neuropsychological testing in 28 men with the premutation but without FXTAS, there were significant executive function deficits relative to control subjects. Cornish et al. ${ }^{40}$ and Moore et al. ${ }^{41}$ found similar deficits in impulsivity in adult males with the premutation, relative to control subjects. Although differences in ascertainment, age, and neuropsychological batteries may yield different results, it is clear that a subgroup of males with the premutation is likely to experience some constellation of social difficulties, ADHD problems, and executive deficits. Nonetheless, many males have no difficulty with neurodevelopmental problems, and the relationship between developmental difficulties and aging difficulties, including FXTAS, is not known.

In females, the percentage with both the premutation and ASD is $5 \%$, which is lower than in male carriers $(10-15 \%) .{ }^{42}$ However, most females with the premutation do not experience developmental or behavioral problems in childhood. The true frequency of ASD in premutation carriers needs to be determined by further evaluation in population samples with minimal bias.

Psychopathology has been studied extensively in adult carriers, including women with the premutation. Depression and anxiety occur at higher rates in carriers, both with and without FXTAS, compared with the general population. ${ }^{4-45}$ Premutation knock-in mice have been created, and they demonstrate enhanced cortisol release with stress, compared with control subjects without the premutation. ${ }^{46}$ In the context of human carriers, there is often considerable stress due to raising children with FXS or from participation in care of a parent who may be suffering from FXTAS. In female carriers, higher levels of anxiety, as measured by the Symptom Checklist-90, correlate with more atrophy in the hippocampus. ${ }^{47}$

Although most individuals with the premutation have a normal IQ, those in the upper range of the premutation have a reduction of their FMRP level and may therefore experience more developmental problems and symptoms of FXS. Many of these individuals have a double hit, with both lowering of FMRP and elevation of FMRI mRNA levels. These individuals usually have a higher IQ than those with the full mutation and FXS, although additional phenotypic involvement is currently being explored, including the possibility of higher rates of psychosis than are seen in FXS.

\section{PHENOTYPE OF FRAGILE X SYNDROME}

Males with FXS have characteristic behavioral features that include hyperactivity, impulsivity, attention problems, poor eye contact, shyness, self-talk, hand-flapping, hand-biting, hyperarousal to sensory stimuli, mood instability, and anxiety. ${ }^{18}$ They demonstrate an enhanced 
sympathetic response, as measured by the sweat response in the hand, to all types of sensory stimuli; the enhanced sympathetic response correlates inversely with the level of FMRP. ${ }^{48}$ A variety of anxiety disorders are common in both males and females with FXS, including selective mutism, social phobia, and specific phobia (L. Cordiero et al., personal communication). Aggression occurs in approximately $30 \%$ of males, seen most commonly in adolescence. Physical features include loose connective tissue, leading to hyperextensible finger joints, doublejointed thumbs, prominent ears, flat feet, and soft skin. In addition, patients with FXS in adulthood usually have a long face, macroorchidism (testicle volume $>35 \mathrm{~mL}$ ), and a high arched palate.

Females with FXS and the full mutation have a variable phenotype, depending on the activation ratio and the level of FMRP. They often have prominent ears, attention problems, and impulsivity and executive function deficits even when their IQ is in the normal range. ${ }^{18}$ Shyness, selective mutism, specific phobias, social anxiety, and social deficits are common (L. Cordiero et al., personal communication).

\section{ASSOCIATION BETWEEN FRAGILE $X$ AND AUTISM}

The strong association between FXS and autism is based on the molecular overlap between the two disorders. The Autism Diagnostic Interview-Revised (ADI-R) ${ }^{49}$ and the Autism Diagnostic Observation Schedule $(\mathrm{ADOS})^{50}$ are currently considered gold standard diagnostic tools for autism. From studies using these tools, the prevalence of autism in individuals with FXS is reported to be approximately $18 \%-36 \% .^{12,13,42,51}$ The entire spectrum of autism is represented in children with FXS. Approximately 43\%-67\% of individuals with FXS have an element of ASD. ${ }^{13,42,51}$ An even larger percentage of individuals with FXS (i.e., 50\%-90\%) have some symptoms of autism, such as poor eye contact, unusual hand mannerisms, perseverative speech, and other features seen in autism, even though they may not meet the full criteria for an ASD. ${ }^{52-56}$ In females with FXS, however, the percentage of ASD is lower, at $20-23 \% .{ }^{42,57}$

The fragile $\mathrm{X}$ mutation is the leading single-gene mutation known to cause autism and ASD. ${ }^{1}$ Of those already diagnosed with autism, 3-6\% also have FXS. ${ }^{1-3,58-60}$ Although we do not know why some individuals with FXS also have autism and others do not, it has been suggested there may be secondary gene effects additive to the FMRI mutation that lead to the development of autism. ${ }^{12}$ One example of a secondary genetic effect that makes autism more common in FXS is the Prader-Willi phenotype of FXS. Individuals with this phenotype have FXS in addition to hyperphagia, obesity, and a lack of satiation after meals, similar to features seen in Prader-
Willi syndrome. That syndrome is associated with a deletion of $15 \mathrm{q} 11.2 \sim \mathrm{q} 13$, maternal uniparental disomy of chromosome 15 , or imprinting center mutations. Instead of these classic Prader-Willi chromosome 15 abnormalities, however, individuals with the Prader-Willi phenotype of FXS have lowered expression of the cytoplasmic interacting FMR1 protein 1 gene (CYFIP1, located in the $15 q$ deletion region of Prader-Willi syndrome), relative both to normal control subjects and to subjects with FXS but without the Prader-Willi phenotype. ${ }^{61}$ In addition, approximately $70 \%$ of those with the Prader-Willi phenotype also have ASD. Why there is downregulation of CYFIP1 in this subgroup of individuals with FXS is not known, but the deficit of CYFIP1, a protein thought to be important for neuronal migration and synaptic plasticity, coupled with the FMRP deficit, apparently leads to hypothalamic dysfunction, including smaller genitalia, delayed puberty, and appetite enhancement. ${ }^{61}$

Children with comorbid autism and FXS are more cognitively impaired, have poorer verbal skills, more severe social deficits, and lower adaptive functioning than do children with FXS alone. ${ }^{12-14,62-65}$ Their language is more impaired in receptive language and theory of mind, even after controlling for their lower nonverbal IQ relative to those with only FXS. ${ }^{65}$ Seizures also appear to be more frequent in children who have both FXS and ASD (28\%) than in children with FXS without autism (12\%). ${ }^{15}$ Autism has been found to co-occur more frequently in individuals with FXS and seizures than in those without seizures (BerryKravis et al., unpublished data).

Macrocephaly is another common phenotype seen both in children with FXS and in those with idiopathic autism. ${ }^{66,67}$ The rate of increase in head circumference appears to be faster in children with FXS and ASD than in children with FXS without ASD. ${ }^{66} P T E N$, a gene involved in regulation of cell growth, has been hypothesized to be involved in this process, and a mutation in PTEN was found in $18 \%$ of individuals with idiopathic autism and macrocephaly. ${ }^{68}$ The lack of FMRP in FXS also downregulates PTEN expression, and this is thought to contribute to the etiology of macrocephaly in FXS (J.C. Darnell, personal communication).

There are similarities in the underlying neuroanatomy of FXS and of autism without FXS. Neuroimaging studies have found hypoplasia of the cerebellar vermis both in individuals with FXS ${ }^{69,70}$ and in those with autism. ${ }^{71-73}$ The posterior cerebellar area is involved in motor function, cognition, sensory perception, and possibly also communication and stereotypic behaviors. ${ }^{73,74}$ The size of the cerebellar vermis lobules VI and VII has been found to be negatively correlated with measures of communication impairment and stereotypic behaviors in children with FXS. ${ }^{74}$

There is also parietal lobe dysfunction in individuals with FXS and in those with autism. Specifically, there appears to be a deficit in the dorsal stream processing in 
both disorders. The dorsal stream is a processing stream projected from V1 of the visual cortex dorsally through the parietal lobe; it is necessary for visual control of action. The ventral stream projects ventrally through the temporal lobe and is important for pattern recognition and object identification. ${ }^{75,76}$ Deficits in visuomotor skills, visuospatial skills, and mathematical performance in individuals with FXS may be tied to deficits in dorsal stream processing. ${ }^{77}$ Likewise, in individuals with autism, there are also impairments in elements of dorsal stream processing that are important in biological motion processing and smooth pursuit eye movements. ${ }^{78-80}$

Although there are many similarities in MRI abnormalities observed in FXS with and without autism, there are also important differences. Hazlett et al ${ }^{81}$ showed that young children with both FXS and autism have a larger caudate nucleus and a smaller amygdala than do young children with autism but not FXS. Even though the phenotype is similar in terms of degree of autism on standardized testing, the genetic underpinning of the autism appears to determine the CNS structure.

Multiple neurophysiological studies have shown hyperarousal of the autonomic nervous system through enhanced sympathetic responses ${ }^{48,82}$ and decreased vagal tone ${ }^{83-85}$ in individuals with FXS. Individuals with comorbid FXS and autism experience even more hyperarousal and intolerance to environmental stimuli, particularly with transitions, than those affected by FXS but not autism. ${ }^{83,86}$ Sensorimotor processing deficits have also been shown in prepulse inhibition studies of children with $\mathrm{FXS}^{87,88}$ and individuals with autism. ${ }^{89} \mathrm{Be}-$ cause this gating or filtering system is abnormal in FXS and autism, these individuals experience a heightened sensitivity to sensory stimulation, cannot attenuate sensory responses well, and have a difficult time attending selectively to a pertinent stimulus. ${ }^{88,90}$

The strong behavioral, neuroanatomical, and neurophysiological associations have important implications for furthering our understanding of the neurobiology of autistic spectrum behaviors, both in individuals with FXS and in individuals with autistic disorder. Moreover, it suggests possible overlapping mechanisms and common pathways for the two disorders. Through our knowledge of FXS, a clearly delineated single-gene disorder with alterations in gene expression and protein synthesis, we gain more understanding about idiopathic autism, a disorder with unclear and probably multiple etiologies.

\section{MOLECULAR BIOLOGY AND ANIMAL MODELS}

The development of animal models of FXS has greatly advanced our understanding of the pathophysiology of this disorder. ${ }^{91}$ There is currently a model with loss of activity of the FMRI homolog in Drosophila, ${ }^{92}$ as well as the Fmrl knockout (KO) mouse model. ${ }^{93}$ The Drosophila model has shown neuronal and behavioral phenotypes that are potential correlates to deficits observed in FXS, exhibiting defects in circadian rhythms, synaptic branching, courtship behavior, and cognition. ${ }^{92,94-97}$ The Fmrl KO also show features representative of FXS, such as hyperactivity, increased sensitivity to audiogenic seizures, macroorchidism, and dendritic spine abnormalities, which may be explained by observed abnormalities in synaptic plasticity in the Fmrl KO, including exaggeration of long-term depression (LTD) and deficits in long-term potentiation (LTP). ${ }^{93,98,99}$

FMRP, an mRNA-binding protein, appears to repress translation and inhibit protein synthesis at the synapse. ${ }^{100}$ The lack of FMRP in individuals with FXS leads to excess basal translation and upregulation of several proteins, including those normally regulated by group I metabotropic glutamate receptor (mGluR1 and mGluR5) activated pathways ${ }^{101}$ (FIG. 1). Bear et al. ${ }^{101}$ have proposed the mGluR theory of fragile $\mathrm{X}$, suggesting that the deficits associated with FXS are related to upregulation of mGluR1/5 pathways and that treatment with mGluR5 negative modulators would be reasonable targeted treatments for FXS. ${ }^{98}$

The mGluR1 receptors are present mainly in the cerebellum and hippocampus, whereas the mGluR5 receptors are present throughout the brain except in cerebellum. ${ }^{102}$ The broader distribution of mGluR5 receptors, in conjunction with toxicity in the form of motor deficits observed in animal models treated with mGluR1 blockers, point to mGluR5 receptors as the better initial target for pharmacotherapy of FXS. Both FMRP and mGluRs play important roles in synaptogenesis and synaptic plasticity. Abnormal dendritic spine morphology is seen in both humans and mice lacking FMRP. ${ }^{103-105}$ The cerebral cortex of adult Fmrl KO mice and autopsy specimens from individuals with FXS both show increased density of long, thin, tortuous postsynaptic dendritic spines, which are normally seen in early neocortical development. ${ }^{103,104}$ As dendritic spines mature, they change from being long and thin protrusions into short, mushroom-shaped structures. ${ }^{106}$ The increased density and increased length of these spines compared with control subjects indicates a deficit in the pruning of unnecessary synaptic contacts and an immaturity of the spines in those with FXS. Thus, it appears that FMRP is required for the important processes of synapse stabilization and pruning during synapse maturation.

Equally important is the role of group I mGluRs in long-term synaptic plasticity, involving long-term depression (LTD) in the hippocampus and at the parallel Purkinje cell synapse of the cerebellum ${ }^{107-110}$ and longterm potentiation (LTP) in the amygdala. ${ }^{111}$ Lack of FMRP-mediated inhibitory control leading to excessive mGluR1/5-activated protein synthesis also results in en- 
hanced mGluR-dependent hippocampal ${ }^{109}$ and cerebellar LTD, ${ }^{112}$ reduction of synaptic AMPA receptors, ${ }^{101,113}$ immature-appearing elongated dendritic processes, ${ }^{114,115}$ and abnormal epileptiform discharges. ${ }^{116}$

Support for the mGluR theory comes from a study with Fmrl KO mice that are also heterozygous for a null mutation in the gene coding for the mGluR5 receptor, resulting in $50 \%$ reduction in mGluR5 expression. ${ }^{98}$ The various phenotypes rescued by genetically reducing mGluR5 expression in these Fmrl KO mice included abnormal ocular dominance plasticity, increased density of dendritic spines on cortical pyramidal neurons, increased basal protein synthesis in the hippocampus, exaggerated inhibitory avoidance extinction, audiogenic seizures, and accelerated body growth. This supports the prior proposal of Bear et al., ${ }^{102}$ that the excessive mGluR5 signaling in the Fmrl KO model could be responsible for the psychiatric and neurological symptoms seen in FXS, such as poor cognitive development, seizures, anxiety, and movement disorders (stereotypic motor movements), as well as the accelerated body growth.

Studies administering mGluR5 negative modulators in animal models of fragile $\mathrm{X}$ lend further support to the mGluR theory. MPEP (2-methyl-6-phenylethynyl pyridine hydrochloride) is a potent, highly selective negative modulator of mGluR5 receptors. ${ }^{117}$ In vitro, both MPEP and fenobam, another mGluR5 negative modulator, were able to rescue abnormal morphology of hippocampal neurons from Fmrl KO mice, and in vitro MPEP rescued excessive AMPA receptor internalization in FMRP-deficient cultured neurons. ${ }^{113}$ When given to Fmrl KO mice, MPEP reversed audiogenic seizures, epileptiform discharges, and open field hyperactivity and rescued the defect in prepulse inhibition of startle. ${ }^{116,118,119}$ When MPEP or lithium (which reduces mGluR signaling to activate translation) was given to $\mathrm{dFmrl}$ loss-of-function Drosophila mutants, abnormal phenotypes were reversed, including courtship behavior, memory, and brain structural abnormalities, presumably through the reduction of mGluR activity. ${ }^{92}$ MPEP is too toxic for use in humans, however, although other mGluR5 negative modulators are being developed for use in humans with FXS (discussed in the next section, Targeted Treatments in Humans).

The GABAergic system has also been hypothesized to play an important role in the pathogenesis of FXS. Nearly $30-50 \%$ of all synapses in the CNS of mammals are GABAergic. ${ }^{120}$ A major inhibitory neurotransmitter receptors in the brain, GABA is important in anxiety, depression, epilepsy, insomnia, and learning and memory. ${ }^{121}$ GABA-mediated inhibition is critical for terminating ictal discharges and the spread of hyperexcitability, which can lead to seizures. ${ }^{122}$ Direct binding between FMRP and the mRNA of the $\delta$-subunit of the $\mathrm{GABA}_{\mathrm{A}}$ receptor has been shown. ${ }^{123}$ In the absence of FMRP, expression of this subunit is disrupted, with a reduction of protein levels. Reduced expression and dysfunction of several subunits of the $\mathrm{GABA}_{\mathrm{A}}$ receptor $(\alpha 1, \alpha 3, \alpha 4 ; \beta 1, \beta 2 ; \gamma 1$, $\gamma 2 ; \delta$ ) has been shown in fragile $\mathrm{X}$ animal models. ${ }^{124-126}$ In Drosophila, dFmrl mutants destined to die from glutamate toxicity after eating glutamate-containing food were rescued after administering molecules involved in the GABAergic pathway. ${ }^{126}$ In addition, abnormal male courtship behavior and mushroom body deficits were reversed with exposure to these molecules.

GABAergic mechanisms to downregulate glutamate release and modulate mGluR overactivity have been investigated. $\mathrm{GABA}_{\mathrm{B}}$ receptor agonists, such as baclofen, inhibit both presynaptic release of glutamate and postsynaptic transmission, as well as intracellular signaling downstream from mGluR5. ${ }^{127,128}$ Baclofen has been shown to be efficacious in treating irritability and selfinjurious behaviors in cognitively impaired individuals, ${ }^{129}$ as well as hyperactivity and marble burying ${ }^{130}$ and audiogenic seizure phenotypes in Fmrl KO mice. ${ }^{131}$

\section{TARGETED TREATMENTS IN HUMANS}

These are exciting times for researchers and clinicians who work with individuals with FXS, because of increasing knowledge about the pathophysiology of the disorder and treatments that may be effective in treating the core deficits in FXS. We are beginning to see well-designed, large-scale, double-blind, placebo-controlled clinical trials of neuropharmacologic treatments aimed at the underlying disorder for individuals with FXS (FIG. 1).

The first mGluR5 negative modulator (FIG. 1, mechanism 1) to be studied in humans with FXS was the imidazole derivative fenobam, a highly selective mGluR5 blocker. ${ }^{132}$ The safety and pharmacokinetics of this medication were studied in human subjects with FXS after a single dose. Rapid reduction in hyperactivity and anxiety was observed in most subjects with FXS, and $50 \%$ of the cohort of 12 patients showed at least a $20 \%$ improvement in prepulse inhibition. ${ }^{133}$ There were no safety concerns in the single-dose trial. Clinical trials are currently underway to study longer treatment with other mGluR5 negative modulators in individuals with FXS, including STX107 (Seaside Therapeutics, Cambridge, MA; just completed phase I testing, expected to enter phase II trials in FXS this year), AFQ056 (Novartis, Basel, Switzerland; recently completed phase II safety and efficacy trial in FXS in Europe), and RO4917523 (Hoffmann-La Roche, Basel, Switzerland; in phase II safety and exploratory efficacy trial in FXS in the USA). See further at http://www.clinicaltrials.gov.

Lithium (FIG. 1, mechanism 1) is another targeted treatment for FXS that can downregulate mGluR5 signaling to activate translation by inhibiting inositol phosphate turnover, thereby attenuating phospholipase $\mathrm{C}$ en- 
zyme activity, and also by inhibiting glycogen synthase kinase $3 \beta .{ }^{134}$ In the Drosophila model of FXS, lithium improved naïve courtship behavior, as well as immediate recall and short term memory. ${ }^{92}$ An open-label trial of lithium in 15 patients with FXS demonstrated significant improvement in behavior and verbal memory, in addition to normalization of abnormal ERK phosphorylation rates in lymphocytes. ${ }^{135}$

The deficit in cortical LTP observed in the Fmrl KO mouse model, ${ }^{136}$ coupled with reversal of hippocampal LTP deficits in KO mouse BDNF ${ }^{137}$ induced by ampakines, has inspired clinical trial of an ampakine known to increase LTP (AMPA receptor activator; FIG. 1, mechanism 3). Specifically, a double-blind placebo-controlled trial of the effects of CX516 (Ampalex; Cortex Pharmaceuticals, Irvine, CA) on safety and cognitive and behavioral efficacy measures was conducted in a cohort of individuals with FXS or autism ${ }^{138}$ (see also http://www. clinicaltrials.gov). Conceptually, it was thought that CX516 would help compensate or correct the AMPA receptor deficit resulting from mGluR pathway overactivity. However, CX516 is a very weak ampakine, and no improvements were seen except in the group of patients cotreated with an antipsychotic known to potentiate ampakine activity. A more potent ampakine molecule might show success in FXS, but such molecules have not yet come to clinical trial.

Minocycline (FIG. 1, mechanism 2), a widely used antibiotic used to treat acne and skin infections, is another promising drug that may target core symptoms of FXS and autism. Minocycline inhibits matrix metalloproteinase-9 (MMP-9) and reduces inflammation in the central nervous system. Matrix metalloproteinases are enzymes involved in synaptic plasticity. MMP-9 translation is normally inhibited by FMRP, and thus the enzyme level is elevated in FXS and is associated with immature dendritic spine morphology. ${ }^{139,140}$ Administration of minocycline to Fmrl KO mice resulted in maturation of their hippocampal dendritic spines and normalization of behaviors, including decreased anxiety and improved exploration skills. ${ }^{140}$ Off-label use of minocycline to treat 50 individuals with FXS resulted in twothirds of families noticing positive improvements in the child's language, attention, or behavior while on the medication. ${ }^{141}$ An open-label trial is ongoing to investigate the effects of minocycline in children with regressive autism, and an open-label trial has recently been completed in adolescents and adults with FXS; in addition a double-blind, placebo-controlled clinical trial is in progress for children and adolescents with FXS (http:// www.clincaltrials.gov).

Some of the most problematic and difficult symptoms for parents to handle in their children with FXS and autism are behavioral problems, including self-injurious behaviors, aggression, and irritability. ${ }^{142}$ Risperidone, an atypical antipsychotic, has recently been approved by the U.S. Food and Drug Administration to treat irritability in children with autism. Patients with FXS were included in the cohort of patients with intellectual disability and aggression who responded favorably to risperidone in the trial reported by Aman et al. ${ }^{143}$ Adverse effects of risperidone include increased appetite, weight gain $(2.7 \mathrm{~kg}$ over 8 weeks), and fatigue.

Aripiprazole causes less weight gain than risperidone, and it has shown an overall response rate of $>70 \%$ in children with FXS when used in low doses: $2.5-5.0 \mathrm{mg}$ in adolescents and even lower doses for younger children (e.g., $<1 \mathrm{mg}$ at bedtime). ${ }^{134}$ Aripiprazole targets hyperactivity, aggression, anxiety, distractibility, mood instability, and aberrant social behaviors, resulting in multiple benefits of treatment. Weight gain can be a significant adverse effect of aripiprazole, however, so this should be monitored closely. Aripiprazole has shown positive response effects in a formal placebo-controlled trial targeting irritable behavior in autism, ${ }^{144}$ an open-label trial of aripiprazole in FXS has just recently been completed with positive results ${ }^{145}$ (see Erickson et al., page 258) and a double-blind placebo-controlled trial is planned. Understandably, however, the hope has been to find alternative medications for clinical use that have even better safety and tolerability profiles.

$\mathrm{GABA}_{\mathrm{B}}$ receptor-mediated signaling antagonizes the effects of mGluRs in Fmrl KO mice, and may be therapeutically beneficial for individuals with FXS. ${ }^{131} \mathrm{~A}$ double-blind, placebo-controlled, crossover trial to determine the efficacy of the arbaclofen (FIG. 1, mechanism 4) for improving aggression and irritability in individuals with FXS, ASD, or both FXS and ASD has just been completed. Arbaclofen is the right-sided enantiomer of baclofen, and it is significantly more potent than $S$-baclofen or racemic baclofen as a $\mathrm{GABA}_{\mathrm{B}}$ agonist. Arbaclofen is thought to work indirectly on mGluR5 signaling in FXS by lowering the level of glutamate at the synapse and thereby reducing glutamate-mediated activation of the receptor.

For the future, we can expect various combinations of targeted treatments (e.g., mGluR5 negative modulators, arbaclofen, minocycline, lithium, ampakines, or other modulators as yet unidentified) to work on neural pathways rendered abnormal by loss of FMRP and to normalize synaptic plasticity. These will be combined with enhanced educational and behavioral interventions to maximize development of appropriate synaptic connections in FXS. The future looks promising for reversing the intellectual and behavioral problems of individuals with FXS, and perhaps also related phenotypes of autism with overlapping molecular mechanisms.

Acknowledgments: We gratefully acknowledge all the wonderful families and individuals with fragile $\mathrm{X}$ and autism 
spectrum disorders who participate in research, enabling the advancement of knowledge in the field of neurodevelopmental disorders and targeted treatments. This work was supported by grants from the National Fragile X Foundation, from the National Institutes of Health (National Institute on Aging, AG032115; National Institute of Child Health and Human Development, HD036071; National Institute of Dental and Craniofacial Research, DE019583; and National Center for Research Resources, UL1RR024146), from the U.S. Health and Human Services Administration on Developmental Disabilities (90DD0596), and from the Illinois-Eastern Iowa Kiwanis Spastic Paralysis and Related Disorders Foundation (E.B.K).

\section{REFERENCES}

1. Hagerman RJ, Rivera SM, Hagerman PJ. The fragile X family of disorders: a model for autism and targeted treatments. Curr Pediatr Rev 2008;4:40-52.

2. Reddy KS. Cytogenetic abnormalities and fragile-X syndrome in autism spectrum disorder. BMC Med Genet 2005;6:3.

3. van Karnebeek CD, Jansweijer MC, Leenders AG, Offringa M, Hennekam RC. Diagnostic investigations in individuals with mental retardation: a systematic literature review of their usefulness. Eur J Hum Genet 2005;13:6-25.

4. Fernandez-Carvajal I, Walichiewicz P, Xiaosen X, Pan R, Hagerman PJ, Tassone F. Screening for expanded alleles of the FMRI gene in blood spots from newborn males in a Spanish population. J Mol Diagn 2009;11:324-329.

5. Hagerman PJ. The fragile $X$ prevalence paradox [Erratum in: J Med Genet 2008;45:768]. J Med Genet 2008;45:498-499.

6. Dombrowski C, Lévesque S, Morel ML, Rouillard P, Morgan K, Rousseau F. Premutation and intermediate-size FMR1 alleles in 10572 males from the general population: loss of an AGG interruption is a late event in the generation of fragile $\mathrm{X}$ syndrome alleles. Hum Mol Genet 2002;11:371-378.

7. Verkerk AJ, Pieretti M, Sutcliffe JS, et al. Identification of a gene (FMR-1) containing a CGG repeat coincident with a breakpoint cluster region exhibiting length variation in fragile $\mathrm{X}$ syndrome. Cell 1991;65:905-914.

8. Qin M, Kang J, Burlin TV, Jiang C, Smith CB. Postadolescent changes in regional cerebral protein synthesis: an in vivo study in the FMR1 null mouse. J Neurosci 2005;25:5087-5095.

9. Bassell GJ, Warren ST. Fragile X syndrome: loss of local mRNA regulation alters synaptic development and function. Neuron 2008;60:201-214.

10. Tassone F, Hagerman RJ, Iklé DN, et al. FMRP expression as a potential prognostic indicator in fragile X syndrome. Am J Med Genet 1999;84:250-261.

11. Loesch DZ, Huggins RM, Hagerman RJ. Phenotypic variation and FMRP levels in fragile X. Ment Retard Dev Disabil Res Rev 2004;10:31-41.

12. Rogers SJ, Wehner DE, Hagerman R. The behavioral phenotype in fragile X: symptoms of autism in very young children with fragile X syndrome, idiopathic autism, and other developmental disorders. J Dev Behav Pediatr 2001;22:409-417.

13. Kaufmann WE, Cortell R, Kau AS, et al. Autism spectrum disorder in fragile X syndrome: communication, social interaction, and specific behaviors. Am J Med Genet 2004;129A:225-234.

14. Loesch DZ, Bui QM, Dissanayake C, et al. Molecular and cognitive predictors of the continuum of autistic behaviours in fragile X. Neurosci Biobehav Rev 2007;31:315-326.

15. Garcia-Nonell C, Ratera ER, Harris S, et al. Secondary medical diagnosis in fragile $\mathrm{X}$ syndrome with and without autism spectrum disorder. Am J Med Genet A 2008;146A:1911-1916.

16. de Vries BB, Wiegers AM, Smits AP, et al. Mental status of females with an FMR1 gene full mutation. Am J Hum Genet 1996;58:1025-1032.

17. Bennetto L, Pennington BF. Neuropsychology. In: Hagerman RJ, Hagerman PJ, editors. Fragile X syndrome: diagnosis, treatment, and research. 3rd ed. Baltimore: Johns Hopkins University Press, 2002:206-248.
18. Hagerman RJ. Physical and behavioral phenotype. In: Hagerman RJ, Hagerman PJ, editors. Fragile X syndrome: diagnosis, treatment, and research. 3rd ed. Baltimore: Johns Hopkins University Press, 2002:3-109.

19. Cronister A, Schreiner R, Wittenberger M, Amiri K, Harris K, Hagerman RJ. Heterozygous fragile X female: historical, physical, cognitive, and cytogenetic features. Am J Med Genet 1991; 38:269-274.

20. Sullivan AK, Marcus M, Epstein MP, et al. Association of FMRI repeat size with ovarian dysfunction. Hum Reprod 2005;20:402412 .

21. Wittenberger MD, Hagerman RJ, Sherman SL, et al. The FMRI premutation and reproduction. Fertil Steril 2007;87:456-465.

22. Tassone F, Hagerman RJ, Taylor AK, Gane LW, Godfrey TE, Hagerman PJ. Elevated levels of FMRI mRNA in carrier males: a new mechanism of involvement in the fragile- $X$ syndrome. Am J Hum Genet 2000;66:6-15.

23. Hagerman RJ. Fragile X Syndrome. In: Cassidy SB, Allanson JE, editors. Management of genetic syndromes. 3rd ed. New York: Wiley \& Sons, 2010:397-411.

24. Jacquemont S, Hagerman RJ, Leehey MA, et al. Penetrance of the fragile $\mathrm{X}$-associated tremor/ataxia syndrome in a premutation carrier population. JAMA 2004;291:460-469.

25. Hagerman RJ, Leavitt BR, Farzin F, et al. Fragile-X-associated tremor/ataxia syndrome (FXTAS) in females with the FMRI premutation. Am J Hum Genet 2004;74:1051-1056.

26. Coffey SM, Cook K, Tartaglia N, et al. Expanded clinical phenotype of women with the FMR1 premutation. Am J Med Genet A 2008;146A:1009-1016.

27. Rodriguez-Revenga L, Madrigal I, Alegret M, Santos M, Milà M Evidence of depressive symptoms in fragile-X syndrome premutated females. Psychiatr Genet 2008;18:153-155.

28. Arocena DG, Iwahashi CK, Won N, et al. Induction of inclusion formation and disruption of lamin $\mathrm{A} / \mathrm{C}$ structure by premutation CGG-repeat RNA in human cultured neural cells. Hum Mol Genet 2005;14:3661-3671.

29. Garcia-Arocena D, Yang JE, Brouwer JR, et al. Fibroblast phenotype in male carriers of FMR1 premutation alleles. Hum Mol Genet 2010;19:299-312.

30. Adams JS, Adams PE, Nguyen D, et al. Volumetric brain changes in females with fragile X-associated tremor/ataxia syndrome (FXTAS). Neurology 2007;69:851-859.

31. Greco CM, Berman RF, Martin RM, et al. Neuropathology of fragile X-associated tremor/ataxia syndrome (FXTAS). Brain 2006;129:243-255.

32. Greco CM, Soontrapornchai K, Wirojanan J, Gould JE, Hagerman PJ, Hagerman RJ. Testicular and pituitary inclusion formation in fragile $\mathrm{X}$ associated tremor/ataxia syndrome. J Urol 2007; 177:1434-1437.

33. Gokden M, Al-Hinti JT, Harik SI. Peripheral nervous system pathology in fragile $\mathrm{X}$ tremor/ataxia syndrome (FXTAS). Neuropathology 2009;29:280-284

34. Chen Y, Tassone F, Berman RF, et al. Murine hippocampal neurons expressing Fmrl gene premutations show early developmental deficits and late degeneration. Hum Mol Genet 2010;19: 196-208.

35. Farzin F, Perry H, Hessl D, et al. Autism spectrum disorders and attention-deficit/hyperactivity disorder in boys with the fragile $\mathrm{X}$ premutation. J Dev Behav Pediatr 2006;27(2 Suppl):S137-S144.

36. Aziz M, Stathopulu E, Callias M, et al. Clinical features of boys with fragile $\mathrm{X}$ premutations and intermediate alleles. Am J Med Genet B Neuropsychiatr Genet 2003;121B:119-127.

37. Bailey DB Jr, Raspa M, Olmsted M, Holiday DB. Co-occurring conditions associated with FMRI gene variations: findings from a national parent survey. Am J Med Genet A 2008;146A:20602069.

38. Hunter JE, Allen EG, Abramowitz A, et al. No evidence for a difference in neuropsychological profile among carriers and noncarriers of the FMRI premutation in adults under the age of 50 . Am J Hum Genet 2008;83:692-702.

39. Grigsby J, Brega AG, Engle K, et al. Cognitive profile of fragile $\mathrm{X}$ premutation carriers with and without fragile $\mathrm{X}$-associated tremor/ataxia syndrome. Neuropsychology 2008;22:48-60. 
40. Cornish KM, Kogan CS, Li L, Turk J, Jacquemont S, Hagerman RJ. Lifespan changes in working memory in fragile $\mathrm{X}$ premutation males. Brain Cogn 2009;69:551-558.

41. Moore CJ, Daly EM, Schmitz N, et al. A neuropsychological investigation of male premutation carriers of fragile $\mathrm{X}$ syndrome. Neuropsychologia 2004;42:1934-1947.

42. Clifford S, Dissanayake C, Bui QM, Huggins R, Taylor AK, Loesch DZ. Autism spectrum phenotype in males and females with fragile $\mathrm{X}$ full mutation and premutation. J Autism Dev Disord 2007;37:738-747.

43. Bourgeois J, Seritan A, Casillas E, et al. Lifetime prevalence of mood and anxiety disorders in fragile $\mathrm{X}$ premutation carriers. $\mathrm{J}$ Clin Psychiatry (in press).

44. Roberts JE, Bailey DB Jr, Mankowski J, et al. Mood and anxiety disorders in females with the FMR1 premutation. Am J Med Genet B Neuropsychiatr Genet 2009;150B:130-139.

45. Bourgeois JA, Coffey SM, Rivera SM, et al. A review of fragile $\mathrm{X}$ premutation disorders: expanding the psychiatric perspective. J Clin Psychiatry 2009;70:852-862.

46. Brouwer JR, Severijnen E, de Jong FH, et al. Altered hypothalamus-pituitary-adrenal gland axis regulation in the expanded CGG-repeat mouse model for fragile X-associated tremor/ataxia syndrome. Psychoneuroendocrinology 2008;33:863-873.

47. Adams PE, Adams JS, Nguyen DV, et al. Psychological symptoms correlate with reduced hippocampal volume in fragile $\mathrm{X}$ premutation carriers. Am J Med Genet B Neuropsychiatr Genet 2010;153B(3):775-785.

48. Miller LJ, McIntosh DN, McGrath J, et al. Electrodermal responses to sensory stimuli in individuals with fragile $X$ syndrome: a preliminary report. Am J Med Genet 1999;83:268-279.

49. Lord C, Rutter M, Le Couteur A. Autism Diagnostic InterviewRevised: a revised version of a diagnostic interview for caregivers of individuals with possible pervasive developmental disorders. J Autism Dev Disord 1994;24:659-685.

50. Lord C, Rutter M, DiLavore PC, Risi S. Autism Diagnostic Observation Schedule. Los Angeles, CA: Western Psychological Services, 1999.

51. Harris SW, Hessl D, Goodlin-Jones B, et al. Autism profiles of males with fragile X syndrome. Am J Ment Retard 2008;113: 427-438.

52. Hagerman RJ, Jackson AW 3rd, Levitas A, Rimland B, Braden M. An analysis of autism in fifty males with the fragile $X$ syndrome. Am J Med Genet A 1986;23:359-374.

53. Bailey DB Jr, Mesibov GB, Hatton DD, Clark RD, Roberts JE, Mayhew L. Autistic behavior in young boys with fragile X syndrome. J Autism Dev Disord 1998;28:499-508.

54. Baumgardner TL, Reiss AL, Freund LS, Abrams MT. Specification of the neurobehavioral phenotype in males with fragile $\mathrm{X}$ syndrome. Pediatrics 1995;95:744-752.

55. Kerby DS, Dawson BL. Autistic features, personality, and adaptive behavior in males with the fragile $\mathrm{X}$ syndrome and no autism. Am J Ment Retard 1994;98:455-462.

56. Merenstein SA, Sobesky WE, Taylor AK, Riddle JE, Tran HX, Hagerman RJ. Molecular-clinical correlations in males with an expanded FMR1 mutation. Am J Med Genet 1996;64:388-394.

57. Hall SS, Lightbody AA, Reiss AL. Compulsive, self-injurious, and autistic behavior in children and adolescents with fragile $\mathrm{X}$ syndrome. Am J Ment Retard 2008;113:44-53.

58. Bailey A, Bolton P, Butler L, et al. Prevalence of the fragile X anomaly amongst autistic twins and singletons. J Child Psychol Psychiatry 1993;34:673-688.

59. Bailey A, Phillips W, Rutter M. Autism: towards an integration of clinical, genetic, neuropsychological, and neurobiological perspectives. J Child Psychol Psychiatry 1996;37:89-126.

60. Dykens EM, Volkmar FR. Medical conditions associated with autism. In: Cohen DJ, Volkmar FR, editors. Handbook of autism and pervasive developmental disorders. 2nd ed. New York: John Wiley \& Sons, 1997:388-410.

61. Nowicki ST, Tassone F, Ono MY, et al. The Prader-Willi phenotype of fragile X syndrome. J Dev Behav Pediatr 2007;28:133138.

62. Roberts J, Price J, Barnes E, et al. Receptive vocabulary, expressive vocabulary, and speech production of boys with fragile $\mathrm{X}$ syndrome in comparison to boys with Down syndrome. Am J Ment Retard 2007;112:177-193.

63. Kau AS, Tierney E, Bukelis I, et al. Social behavior profile in young males with fragile $\mathrm{X}$ syndrome: characteristics and specificity. Am J Med Genet 2004;126A:9-17.

64. Hatton DD, Sideris J, Skinner M, et al. Autistic behavior in children with fragile X syndrome: prevalence, stability, and the impact of FMRP. Am J Med Genet A 2006;140A:1804-1813.

65. Lewis P, Abbeduto L, Murphy M, et al. Cognitive, language and social-cognitive skills of individuals with fragile $\mathrm{X}$ syndrome with and without autism. J Intellect Disabil Res 2006;50:532545.

66. Chiu S, Wegelin JA, Blank J, et al. Early acceleration of head circumference in children with fragile $\mathrm{X}$ syndrome and autism. J Dev Behav Pediatr 2007;28:31-35.

67. Courchesne E, Carper R, Akshoomoff N. Evidence of brain overgrowth in the first year of life in autism. JAMA 2003;290:337344 .

68. Butler MG, Dasouki MJ, Zhou XP, et al. Subset of individuals with autism spectrum disorders and extreme macrocephaly associated with germline PTEN tumour suppressor gene mutations. J Med Genet 2005;42:318-321.

69. Reiss AL, Freund L, Tseng JE, Joshi PK. Neuroanatomy in fragile X females: the posterior fossa. Am J Hum Genet 1991;49:279_ 288.

70. Mostofsky SH, Mazzocco MM, Aakalu G, Warsofsky IS, Denckla MB, Reiss AL. Decreased cerebellar posterior vermis size in fragile $\mathrm{X}$ syndrome: correlation with neurocognitive performance. Neurology 1998;50:121-130.

71. Murakami JW, Courchesne E, Press GA, Yeung-Courchesne R, Hesselink JR. Reduced cerebellar hemisphere size and its relationship to vermal hypoplasia in autism. Arch Neurol 1989;46: 689-694.

72. Ciesielski KT, Harris RJ, Hart BL, Pabst HF. Cerebellar hypoplasia and frontal lobe cognitive deficits in disorders of early childhood. Neuropsychologia 1997;35:643-655.

73. Pierce K, Courchesne E. Evidence for a cerebellar role in reduced exploration and stereotyped behavior in autism. Biol Psychiatry 2001;49:655-664.

74. Mazzocco MM, Kates WR, Baumgardner TL, Freund LS, Reiss AL. Autistic behaviors among girls with fragile X syndrome. J Autism Dev Disord 1997;27:415-435.

75. Van Essen DC, Maunsell HH. Hierarchical organization of the functional streams in the visual cortex. Trends Neurosci 1983;6: 370-375.

76. Sagi D, Julesz B. "Where" and "what" in vision. Science 1985; 228:1217-1219.

77. Kogan CS, Boutet I, Cornish KM, et al. Differential impact of the $F M R 1$ gene on visual processing in fragile $\mathrm{X}$ syndrome. Brain 2004;127:591-601.

78. Spencer J, O'Brien J, Riggs K, Braddick O, Atkinson J, WattamBell J. Motion processing in autism: evidence for a dorsal stream deficiency. Neuroreport 2000;11:2765-2767.

79. Bertone A, Mottron L, Jelenic P, Faubert J. Motion perception in autism: a "complex" issue. J Cogn Neurosci 2003;15:218-225.

80. Blake R, Turner LM, Smoski MJ, Pozdol SL, Stone WL. Visual recognition of biological motion is impaired in children with autism. Psychol Sci 2003;14:151-157.

81. Hazlett HC, Poe MD, Lightbody AA, et al. Teasing apart the heterogeneity of autism: same behavior, different brains in toddlers with fragile $\mathrm{X}$ syndrome and autism. J Neurodev Disord 2009;1:81-90.

82. Hagerman RJ, Miller LJ, McGrath-Clarke J, et al. Influence of stimulants on electrodermal studies in fragile $\mathrm{X}$ syndrome. Microsc Res Tech 2002;57:168-173.

83. Roberts JE, Boccia ML, Bailey DB Jr, Hatton DD, Skinner M. Cardiovascular indices of physiological arousal in boys with fragile X syndrome. Dev Psychobiol 2001;39:107-123.

84. Roberts JE, Boccia ML, Hatton DD, Skinner ML, Sideris J. Temperament and vagal tone in boys with fragile $\mathrm{X}$ syndrome. J Dev Behav Pediatr 2006;27:193-201.

85. Boccia ML, Roberts JE. Behavior and autonomic nervous system function assessed via heart period measures: the case of hyper- 
arousal in boys with fragile X syndrome. Behav Res Methods, Instrum Comput 2000;32:5-10.

86. Cohen IL. A theoretical analysis of the role of hyperarousal in the learning and behavior of fragile X males. Ment Retard Dev Disabil Res Rev 1995;1:286-291.

87. Frankland PW, Wang Y, Rosner B, et al. Sensorimotor gating abnormalities in young males with fragile $\mathrm{X}$ syndrome and FMR1-knockout mice. Mol Psychiatry 2004;9:417-425.

88. Hessl D, Berry-Kravis E, Cordeiro L, et al. Prepulse inhibition in fragile $\mathrm{X}$ syndrome: feasibility, reliability, and implications for treatment. Am J Med Genet B Neuropsychiatr Genet 2009;150B: 545-53.

89. Perry W, Minassian A, Lopez B, Maron L, Lincoln A. Sensorimotor gating deficits in adults with autism. Biol Psychiatry 2007; 61:482-486.

90. Postma P, Kumari V, Hines M, Gray JA. The relationship between prepulse detection and prepulse inhibition of the acoustic startle reflex. Psychophysiology 2001;38:377-382.

91. Greenough WT, Klintsova AY, Irwin SA, Galvez R, Bates KE, Weiler IJ. Synaptic regulation of protein synthesis and the fragile X protein. Proc Natl Acad Sci U S A 2001;98:7101-7106.

92. McBride SM, Choi CH, Wang Y, et al. Pharmacological rescue of synaptic plasticity, courtship behavior, and mushroom body defects in a Drosophila model of fragile X syndrome. Neuron 2005;45:753-764.

93. Bakker CE, Oostra BA. Understanding fragile X syndrome: insights from animal models. Cytogenet Genome Res 2003;100: 111-123.

94. Zhang YQ, Bailey AM, Matthies HJ, et al. Drosophila fragile $\mathrm{X}$-related gene regulates the MAP1B homolog Futsch to control synaptic structure and function. Cell 2001;107:591-603.

95. Dockendorff TC, Su HS, McBride SM, et al. Drosophila lacking dfmrl activity show defects in circadian output and fail to maintain courtship interest. Neuron 2002;34:973-984.

96. Morales J, Hiesinger PR, Schroeder AJ, et al. Drosophila fragile $\mathrm{X}$ protein, DFXR, regulates neuronal morphology and function in the brain. Neuron 2002;34:961-972.

97. Lee A, Li W, Xu K, Bogert BA, Su K, Gao FB. Control of dendritic development by the Drosophila fragile X-related gene involves the small GTPase Rac1. Development 2003;130:55435552.

98. Dolen G, Osterweil E, Rao BS, et al. Correction of fragile X syndrome in mice. Neuron 2007;56:955-962.

99. Bear MF, Dolen G, Osterweil E, Nagarajan N. Fragile X: translation in action. Neuropsychopharmacology 2008;33:84-87.

100. Penagarikano O, Mulle JG, Warren ST. The pathophysiology of fragile X syndrome. Annu Rev Genomics Hum Genet 2007;8: $109-129$.

101. Bear MF, Huber KM, Warren ST. The mGluR theory of fragile $X$ mental retardation. Trends Neurosci 2004;27:370-377.

102. Bear MF. Therapeutic implications of the mGluR theory of fragile X mental retardation. Genes Brain Behav 2005;4:393-398.

103. Comery TA, Harris JB, Willems PJ, et al. Abnormal dendritic spines in fragile $\mathrm{X}$ knockout mice: maturation and pruning deficits. Proc Natl Acad Sci U S A 1997;94:5401-5404.

104. Nimchinsky EA, Oberlander AM, Svoboda K. Abnormal development of dendritic spines in FMRI knock-out mice. J Neurosci 2001;21:5139-5146.

105. Irwin SA, Patel B, Idupulapati M, et al. Abnormal dendritic spine characteristics in the temporal and visual cortices of patients with fragile-X syndrome: a quantitative examination. Am J Med Genet A 2001;98:161-167.

106. Knott GW, Holtmaat A, Wilbrecht L, Welker E, Svoboda K. Spine growth precedes synapse formation in the adult neocortex in vivo. Nat Neurosci 2006;9:1117-1124.

107. Linden DJ. Input-specific induction of cerebellar long-term depression does not require presynaptic alteration. Learn Mem 1994;1:121-128.

108. Anwyl R. Metabotropic glutamate receptors: electrophysiological properties and role in plasticity. Brain Res Brain Res Rev 1999; 29:83-120.
109. Huber KM, Gallagher SM, Warren ST, Bear MF. Altered synaptic plasticity in a mouse model of fragile $\mathrm{X}$ mental retardation. Proc Natl Acad Sci U S A 2002;99:7746-7750.

110. Zheng F, Gallagher JP. Metabotropic glutamate receptors are required for the induction of long-term potentiation. Neuron 1992;9:163-172.

111. Fendt M, Schmid S. Metabotropic glutamate receptors are involved in amygdaloid plasticity. Eur J Neurosci 2002;15:15351541.

112. Koekkoek SK, Yamaguchi K, Milojkovic BA, et al. Deletion of FMR1 in Purkinje ]ells enhances parallel fiber LTD, enlarges spines, and attenuates cerebellar eyelid conditioning in fragile $\mathrm{X}$ syndrome. Neuron 2005;47:339-352.

113. Nakamoto M, Nalavadi V, Epstein MP, Narayanan U, Bassell GJ, Warren ST. Fragile X mental retardation protein deficiency leads to excessive mGluR5-dependent internalization of AMPA receptors. Proc Natl Acad Sci U S A 2007;104:15537-15542.

114. Irwin SA, Galvez R, Weiler IJ, Beckel-Mitchener A, Greenough WT. Brain structure and functions of $F M R 1$ protein. In: Hagerman RJ, Hagerman PJ, editors. Fragile X syndrome: diagnosis, treatment, and research. 3rd ed. Baltimore: Johns Hopkins University Press, 2002:191-205.

115. Beckel-Mitchener A, Greenough WT. Correlates across the structural, functional, and molecular phenotypes of fragile $\mathrm{X}$ syndrome. Ment Retard Dev Disabil Res Rev 2004;10:53-59.

116. Chuang SC, Zhao W, Bauchwitz R, Yan Q, Bianchi R, Wong RK. Prolonged epileptiform discharges induced by altered group I metabotropic glutamate receptor-mediated synaptic responses in hippocampal slices of a fragile X mouse model. J Neurosci 2005; 25:8048-8055.

117. Gasparini F, Lingenhohl K, Stoehr N, et al. 2-Methyl-6-(phenylethynyl)-pyridine (MPEP), a potent, selective and systemically active mGlu5 receptor antagonist. Neuropharmacology 1999;38: 1493-1503.

118. Yan QJ, Rammal M, Tranfaglia M, Bauchwitz RP. Suppression of two major fragile $\mathrm{X}$ syndrome mouse model phenotypes by the mGluR5 antagonist MPEP. Neuropharmacology 2005;49:10531066.

119. de Vrij FM, Levenga J, van der Linde HC, et al. Rescue of behavioral phenotype and neuronal protrusion morphology in Fmrl KO mice. Neurobiol Dis 2008;31:127-132.

120. Paredes RG, Agmo A. GABA and behavior: the role of receptor subtypes [Erratum in: Neurosci Biobehav Rev 1992;16:425]. Neurosci Biobehav Rev 1992;16:145-170.

121. Mihalek RM, Banerjee PK, Korpi ER, et al. Attenuated sensitivity to neuroactive steroids in $\gamma$-aminobutyrate type A receptor delta subunit knockout mice. Proc Natl Acad Sci U S A 1999;96: 12905-12910.

122. Carter RB, Wood PL, Wieland S, et al. Characterization of the anticonvulsant properties of ganaxolone (CCD 1042; $3 \alpha$-hydroxy-3 $\beta$-methyl-5 $\alpha$-pregnan-20-one), a selective, high-affinity,

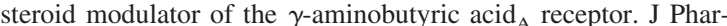
macol Exp Ther 1997;280:1284-1295.

123. Miyashiro KY, Beckel-Mitchener A, Purk TP, et al. RNA cargoes associating with FMRP reveal deficits in cellular functioning in Fmr1 null mice. Neuron 2003;37:417-431.

124. D'Hulst C, De Geest N, Reeve SP, et al. Decreased expression of the $\mathrm{GABA}_{\mathrm{A}}$ receptor in fragile $\mathrm{X}$ syndrome. Brain Res 2006; 1121:238-245.

125. Gantois I, Vandesompele J, Speleman F, et al. Expression profiling suggests underexpression of the $\mathrm{GABA}_{\mathrm{A}}$ receptor subunit delta in the fragile $\mathrm{X}$ knockout mouse model. Neurobiol Dis 2006;21:346-357.

126. Chang S, Bray SM, Li Z, et al. Identification of small molecules rescuing fragile $\mathrm{X}$ syndrome phenotypes in Drosophila. Nat Chem Biol 2008;4:256-263.

127. Isaacson JS, Hille B. GABA ${ }_{B}$-mediated presynaptic inhibition of excitatory transmission and synaptic vesicle dynamics in cultured hippocampal neurons. Neuron 1997;18:143-152.

128. Sohn JW, Lee D, Cho H, et al. Receptor-specific inhibition of $\mathrm{GABA}_{\mathrm{B}}$-activated $\mathrm{K}^{+}$currents by muscarinic and metabotropic glutamate receptors in immature rat hippocampus. J Physiol 2007;580:411-422. 
129. Primrose DA. Treatment of self-injurious behaviour with a GABA ( $\gamma$-aminobutyric acid) analogue. J Ment Defic Res 1979; 23:163-173.

130. Paylor R. Pharmacological modification of behavioral responses in the fragile $\mathrm{X}$ mouse model. Proc Int Fragile X Conf 11th 2008;11:1052 (abstract). Available at http://www.fragilex.org/ html/2008_proceedings.htm.

131. Pacey LK, Heximer SP, Hampson DR. Increased GABA $A_{B}$ receptor-mediated signaling reduces the susceptibility of fragile $\mathrm{X}$ knockout mice to audiogenic seizures. Mol Pharmacol 2009;76: $18-24$.

132. Porter RH, Jaeschke G, Spooren W, et al. Fenobam: a clinically validated nonbenzodiazepine anxiolytic is a potent, selective, and noncompetitive mGlu5 receptor antagonist with inverse agonist activity. J Pharmacol Exp Ther 2005;315:711-721.

133. Berry-Kravis E, Hessl D, Coffey S, et al. A pilot open label, single dose trial of fenobam in adults with fragile $\mathrm{X}$ syndrome. J Med Genet 2009;46:266-271.

134. Hagerman RJ, Berry-Kravis E, Kaufmann WE, et al. Advances in the treatment of fragile X syndrome. Pediatrics 2009;123:378390.

135. Berry-Kravis E, Sumis A, Hervey C, et al. Open-label treatment trial of lithium to target the underlying defect in fragile $\mathrm{X}$ syndrome. J Dev Behav Pediatr 2008;29:293-302.

136. Li J, Pelletier MR, Perez Velazquez JL, Carlen PL. Reduced cortical synaptic plasticity and GluR1 expression associated with fragile X mental retardation protein deficiency. Mol Cell Neurosci 2002;19:138-151.

137. Lauterborn JC, Rex CS, Kramár E, et al. Brain-derived neurotrophic factor rescues synaptic plasticity in a mouse model of fragile X syndrome. J Neurosci 2007;27:10685-10694.
138. Berry-Kravis E, Krause SE, Block SS, et al. Effect of CX516, an AMPA-modulating compound, on cognition and behavior in fragile X syndrome: a controlled trial. J Child Adolesc Psychopharmacol 2006;16:525-540.

139. Bilousova TV, Rusakov DA, Ethell DW, Ethell IM. Matrix metalloproteinase-7 disrupts dendritic spines in hippocampal neurons through NMDA receptor activation. J Neurochem 2006;97:44-56.

140. Bilousova TV, Dansie L, Ngo M, et al. Minocycline promotes dendritic spine maturation and improves behavioural performance in the fragile X mouse model. J Med Genet 2009;46:94102.

141. Utari A, Chonchaiya W, Rivera SM, et al. Side effects of minocycline treatment in patients with fragile $\mathrm{X}$ syndrome and exploration of outcome measures. Am J Intellect Dev Disabil (in press).

142. McCracken JT, McGough J, Shah B, et al. Risperidone in children with autism and serious behavioral problems. N Engl J Med 2002;347:314-321.

143. Aman MG, Gharabawi GM; Special Topic Advisory Panel on Transitioning to Risperidone Therapy in Patients With Mental Retardation and Developmental Disabilities. Treatment of behavior disorders in mental retardation: report on transitioning to atypical antipsychotics, with an emphasis on risperidone. J Clin Psychiatry 2004;65:1197-1210.

144. Owen R, Sikich L, Marcus RN, et al. Aripiprazole in the treatment of irritability in children and adolescents with autistic disorder. Pediatrics 2009;124:1533-1540.

145. Erickson CA, Kohn AE, Diener JT, Stigler KA, Posey DJ, McDougle CJ. A prospective, 12-week open-label study of aripiprazole in fragile X syndrome. Proc Int Fragile X Conf 11th 2008;11:1065-1100. Available at http://www.fragilex.org/ html/2008_proceedings.htm. 